\title{
EDUKASI EVAKUASI GEMPA BUMI SEBAGAI MITIGASI BENCANA DI SMK AD-DA'WAH
}

\author{
Tommy Iduwin*1, Devita Mayasari ${ }^{2}$, Pratiwi Setyaning P $^{3}$, Budi Wicaksono ${ }^{4}$, Dicki Dian $\mathbf{P}^{5}$, \\ Tri Yuhanah ${ }^{6}$ \\ 1,2,3,4,5,6Sekolah Tinggi Teknik-PLN; JL. Lingkar Luar Barat, Duri Kosambi, Cengkareng, Jakarta \\ Barat 11750 \\ Program Studi Teknik Sipil, Fakultas Teknik \\ e-mail: *1 tommyiduwin@sttpln.ac.id
}

\begin{abstract}
Abstrak
SMK Ad Da'wah yang terletak di Kelurahan Duri Kosambi Kecamatan Cengkareng Jakarta Barat merupakan sekolah yang terkena dampak gempa bumi Banten 2018. Setelah peristiwa gempa bumi di bulan Januari 2018, sekolah belum memberikan pelatihan maupun sosialisasi tentang bagaimana langkah-langkah yang harus dilakukan apabila terjadi gempa bumi dan belum mengintegrasikan mengenai materi kesiapsiagaan bencana gempa bumi kedalam mata pelajaran.

Kegiatan edukasi dilakukan dengan metode penyuluhan dan demonstrasi evakuasi gempa bumi oleh tim dan siswa-siswi SMK AD'Da'wah. Narasumber berasal dari Jurusan Teknik Sipil STT PLN Duri Kosambi, Kecamatan Cengkareng, Jakarta Barat, serta dukungan perangkat sekolah SMK $A D^{\prime}$-Da'wah. Dana pendukung dari institusi STT-PLN merupakan aspek penting terselenggaranya kegiatan PKM ini.

Manfaat yang diperoleh dari kegiatan PKM ini antara lain SMK Ad-Da'wah memahami arti pentingnya kesiapsiagaan terhadap bencana gempa bumi sehingga dapat mengurangi korban jiwa dan kerusakan yang ditimbulkan akibat bencana gempa bumi.
\end{abstract}

Kata kunci: Gempa Bumi, Evakuasi, Korban Jiwa

\begin{abstract}
SMK Ad Da'wah which is located at Duri Kosambi, Cengkareng, Jakarta Barat is one of many school that is affected earthquake impact in 2018. After earthquake on January 2018, there is no information about evaquation procedure during earthquake at school. Preparedness due to earthquake disaster also not integrated into their syllabus.

Education activity method applied by using illumination and demonstration about evacuating during the earthquake disaster. It will be applied involve PKM's team and SMK Ad Da'wah's students. The speaker came from Department of Civil Engineering STT PLN Duri Kosambi, Cengkareng, Jakarta Barat. It will be supported by the school itself too. Funds are supported by STT PLN that is an important aspect in the implementation of these activites.

PKM activities are expected to bring the comprehension of the significant earthquake evacuation. It expected could reduce casualties and damage caused by the earthquake disaster.
\end{abstract}


Keywords: Earthquake, Evacuation, Casualties

\section{PENDAHULUAN}

Gempa bumi adalah suatu sentakan asli dari dalam bumi yang kemudian merambat ke permukaan bumi (Katili, 1996). Gempa bumi dapat disebabkan oleh berbagai hal, diantaranya patahan batuan/ sesar (Muhammad, 2008). Gempa bumi sering melanda daerahdaerah di Indonesia, hal ini dikarenakan Indonesia dilalui oleh tiga lempeng yaitu lempeng Indo-Australia, lempeng Eurasia, dan lempeng pasifik. Pertemuan lempeng Indo - Australia dan Eurasia membentang sepanjang barat sumatera, selatan Jawa, Bali dan Nusa Tenggara. Sedangkan pertemuan lempeng Eurasia dan lempeng pasifik terletak di sepanjang maluku (Rahmadi, 2008).

Indonesia merupakan negara yang sarat akan potensi bencana gempa bumi dan tsunami yang disebabkan oleh pergerakan lempeng tektonik. Ini merupakan dampak dari wilayah Indonesia yang terletak di pertemuan dua jalur pegunungan aktif terpanjang di dunia (Wardhana, 1998). Bagian Indonesia Barat dilalui oleh mediteran ring of fire - sirkum pegunungan mediterania, yang memanjang dari laut mediteran di Eropa. Sedangkan di bagian Timur merupakan ujung dari Pacific ring of fire - sirkum api pasifik, yang berasal dari pegunungan Rocky di Benua Amerika (Nungrat, 2001). Selain kedua sirkum tersebut di Indonesia juga terdapat tiga lempeng tektonik yang saling menyusun lempeng bumi Indonesia. Indonesia disusun oleh Lempeng Eurasia. Lempeng Indo-Australia dan Lempeng Pasifik (Cahyadi, 1976). Pertemuan lempeng tektonik tersebut menyebabkan terjadinya penunjaman serta patahan aktif fi fasar lautan dan di daratan. Aktifitas zona tumbukan dan patahan-patahan tersebut berpotensi memicu terjadinya gempa bumi (Krishna S. Pribadi, dkk, 2008)

Pada tahun 2018 BNPB memprediksi akan terjadi 500 gempa tiap bulan. Berdasarkan data diatas sudah selayaknya Indonesia memiliki sebuah sistem diseminasi informasi di bidang kebencanaan termasuk gempa bumi. Kesiapsiagaan merupakan hal yang penting dan harus dibangun pada setiap kelompok masyarakat. Pengalaman menunjukkan bahwa kehancuran akibat bencana dapat dikurangi secara drastis jika semua orang lebih siap menghadapi bencana. Sekolah adalah pusat pendidikan yang tidak hanya memberikan ilmu pengetahuan namun juga bekal untuk kelangsungan hidup. Anak-anak merupakan peserta ajar yang paling cepat dan tidak hanya mampu memadukan pengetahuan baru ke dalam kehidupan sehari-hari tetapi juga menjadi sumber pengetahuan bagi keluarga dan masyarakat dalam hal perilaku yang sehat dan aman yang diapatkan di sekolah. Oleh karena itu, pencegahan bencana menjadi salah satu fokus di sekolah dengan memberdayakan anakanak dan renaja untuk memahami tanda-tanda peringatan bencana dan langkah-langkah yang dapat diambil untuk mengurangi risiko dan mencegah bencana (Kemendiknas, 2009).

Melalui pendidikan diharapkan agar upaya pengurangan risiko bencana dapat mencapai sasaran yang lebih luas dan dapat dikenalkan secara lebih dini kepada seluruh peserta didik. Banyaknya korban jiwa dan kerugian material yang diakibatkan karena bencana gempa bumi 
salah satunya disebabkan karena rendahnya tingkat kesiasiagaan dan minimnya pengetahuan tentang bencana alam. Kesiapsiagaan merupakan salah satu bagian dari upaua pengurangan risiko bencana. Pemahaman dini terhadap konsep dan manajemen kebencanaan menjadi hal yang utama sehingga ketika terjadi bencana timbulnya korban jiwa dan kerugian harta benda dapat diminimalkan.

SMK Ad Da'wah yang terletak di Kelurahan Duri Kosambi Kecamatan Cengkareng Jakarta Barat merupakan sekolah yang terkena dampak gempa bumi Banten 2018. Setelah peristiwa gempa bumi di bulan Januari 2018, sekolah belum memberikan pelatihan maupun sosialisasi tentang bagaimana langkah-langkah yang harus dilakukan apabila terjadi gempa bumi dan belum mengintegrasikan mengenai materi kesiapsiagaan bencana gempa bumi kedalam mata pelajaran. Melalui hasil PKM diharapkan sekolah-sekolah memahami arti pentingnya kesiapsiagaan terhadap bencana gempa bumi sehingga dapat mengurangi korban jiwa dan kerusakan yang ditimbulkan akibat bencana gempa bumi.

Mitra masyarakat yang akan bekerjasama melaksanakan Program Kemitraan Masyarakat (PKM) dengan tim pengusul adalah SMK Ad Da'wah yang berlokasi di Duri Kosambi, Cengkareng, Jakarta Barat. Setelah dilakukan kunjungan diketahui bahwa pengetahuan para siswa dan guru dalam menghadapi serta mengursngi dampak/resiko akibat bencana gempa bumi masih minim. Hal ini perlu segera diatasi dengan adanya edukasi kepada para siswa dan guru untuk meningkatkan kesadaran akan kesiapsiagaan terhadap bencana gempa bumi yang mungkin terjadi. Secara khusus target peserta kegiatan PKM ini adalah :

a. Siswa beserta guru SMK Ad Da'wah yang berminat dalam meningkatkan pengetahuan tentang mitigasi bencana gempa bumi

b. Masyarakat umum yang berminat dalam meningkatkan pengetahuan tentang mitigasi bencana gempa bumi

\section{METODE}

\subsection{Sifat dan Bentuk Kegiatan}

Edukasi evakuasi gempa sebagai mitigasi bencana di SMK Ad Da'wah akan dilaksanakan dalam satu sesi dan diikuti oleh 20-30 peserta. Kegiatan ini akan dilaksanakan dalam waktu satu hari kerja. Setiap peserta akan diberikan materi berupa pengetahuan dan simulasi singkat tentang mitigasi bencana gempa.

Langkah 1 : Peserta edukasi diberikan teori dan pemahaman tentang upaya-upaya yang dilakukan pada saat terjadi dan setelah terjadi gempa bumi untuk meningkatkan pemahaman dan kesadaran masyarakat dalam menghadapi bencana gempa bumi.

Langkah 2 : Peserta diberikan kesempatan bertanya kepada presentator.

Langkah 3 : Peserta melakukan simulasi sederhana saat terjadi dan setelah terjadi gempa bumi. 


\subsection{Diagram Alir Kegiatan}

Kegiatan PKM mengikuti acuan diagram alir berikut :

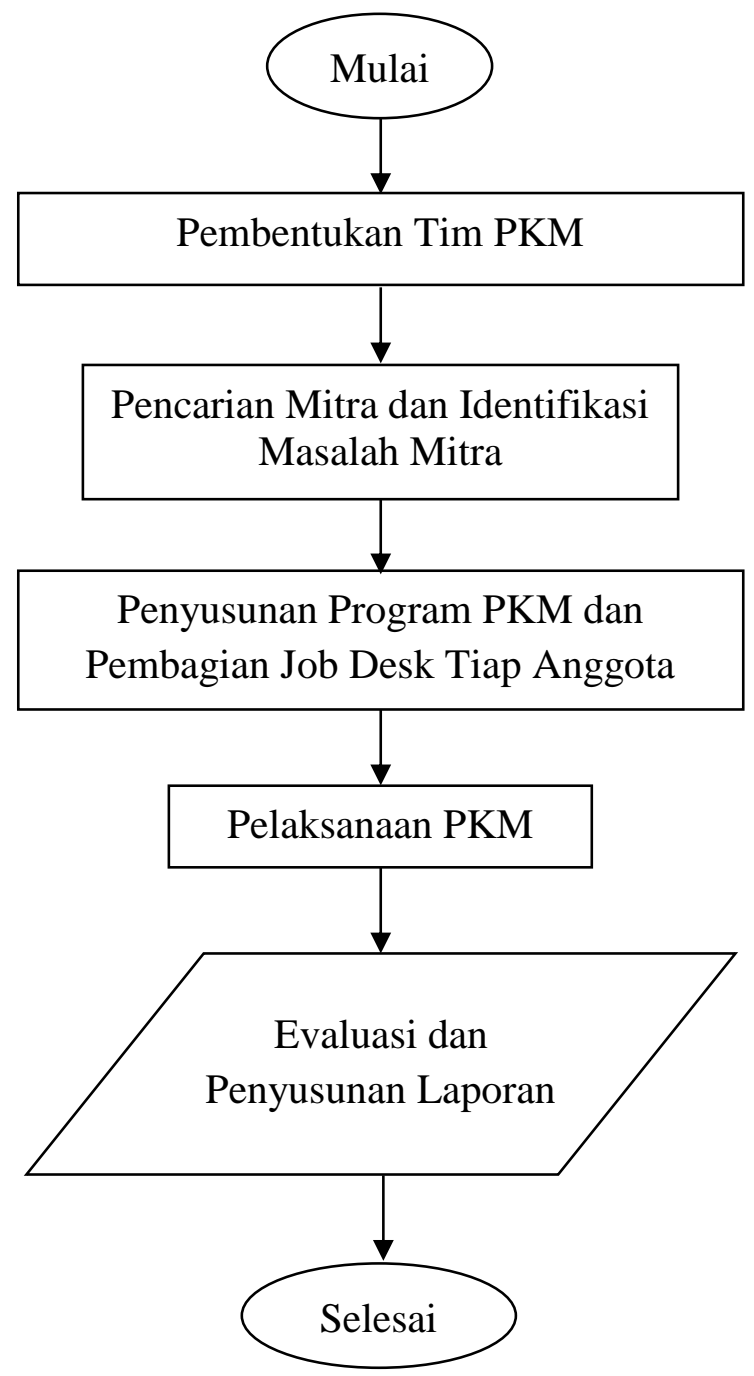

Gambar 1. Diagram Alir Penelitian

\section{HASIL DAN PEMBAHASAN}

Sebelum diadakan kegiatan edukasi evakuasi gempa bumi sebagai mitigasi bencana, kota Jakarta merupakan daerah yang terkena dampak gempa bumi di Banten 2018. Hal ini menimbulkan beberapa permasalahan, diantaranya kepanikan warga, korban gempa dan kerusakan yang ditimbulkan akibat bencana gempa bumi. 
Kegiatan program kemitraan masyarakat ini diawali dengan survei pendahuluan di Bulan Maret 2018. Dari hasil survei tersebut, kemudian dilakukan analisis untuk menentukan kebutuhan mitra. Setelah kebutuhan mitra ditentukan, disusun skenario kegiatan serta dipersiapkan segala bahan dan perlengkapan yang akan digunakan untuk kegiatan edukasi.

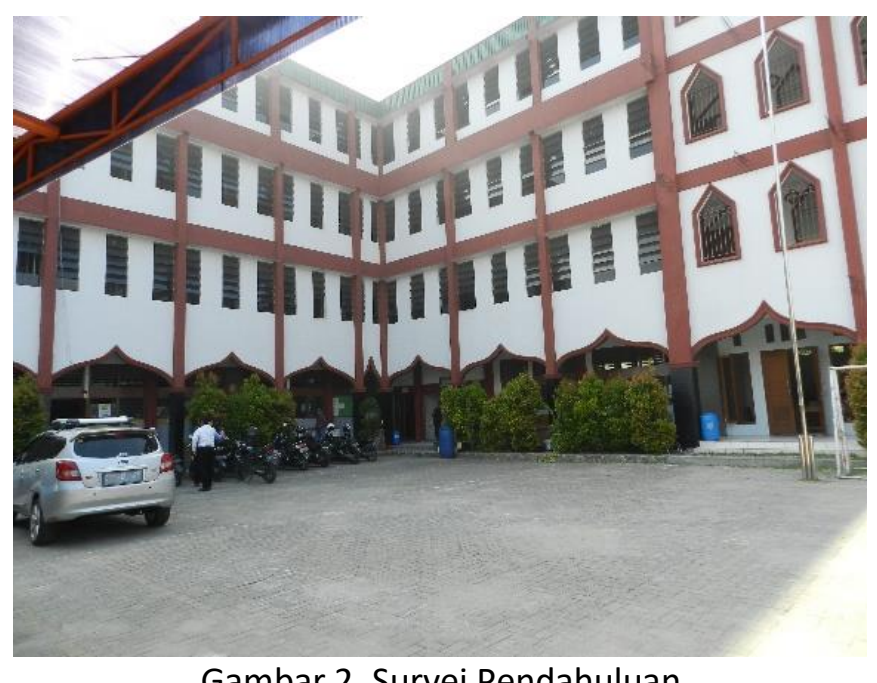

Gambar 2. Survei Pendahuluan

Kegiatan edukasi dimulai dengan sambutan dari kepala sekolah SMK AD-Da'wah dan Ketua Tim PKM STT-PLN. Setelah itu, dilanjutkan dengan kegiatan pre test yang dilakukan oleh siswa dan siswi SMK AD-Da'wah. Kegiatan selanjutnya adalah pemaparan materi tentang edukasi gempa disampaikan oleh Tim PKM STT-PLN. Setelah penyampaian materi edukasi selasai dilakukan kembali kegiatan post tes yang dilakukan oleh siwa dan siswi SMK AD-Da'wah.

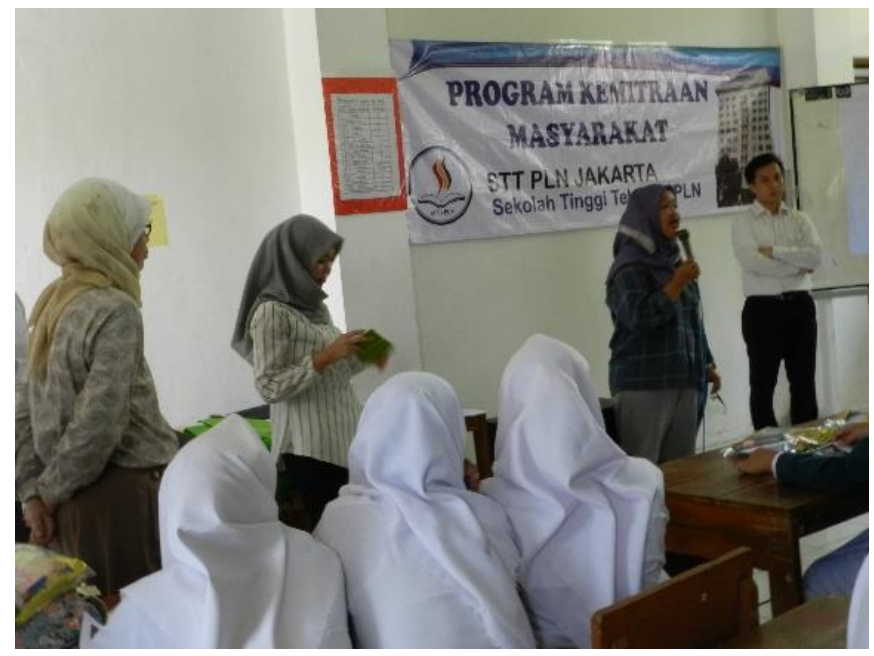

Gambar 3. Pemaparan Materi 


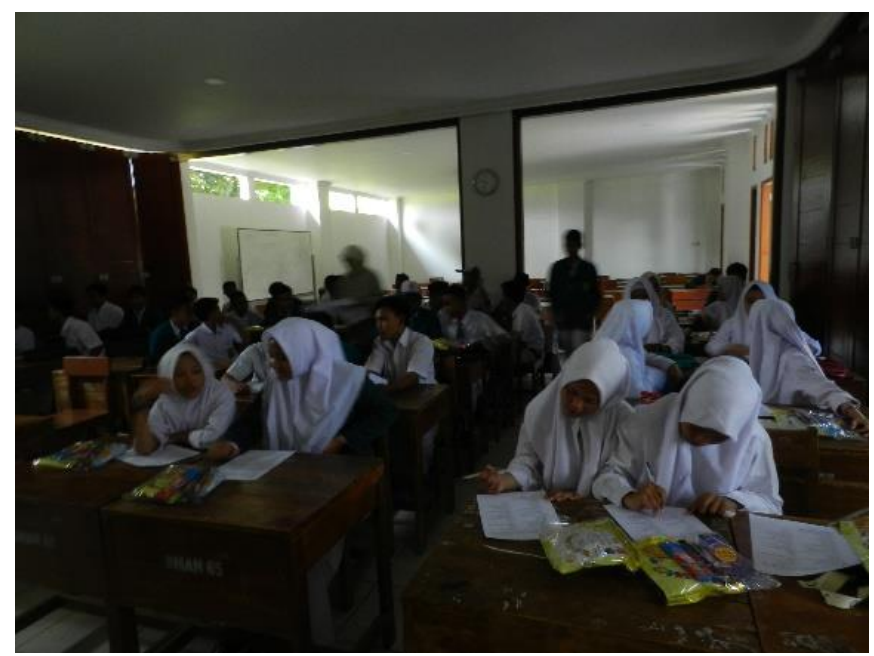

Gambar 4. Kegiatan Pre dan Post Test

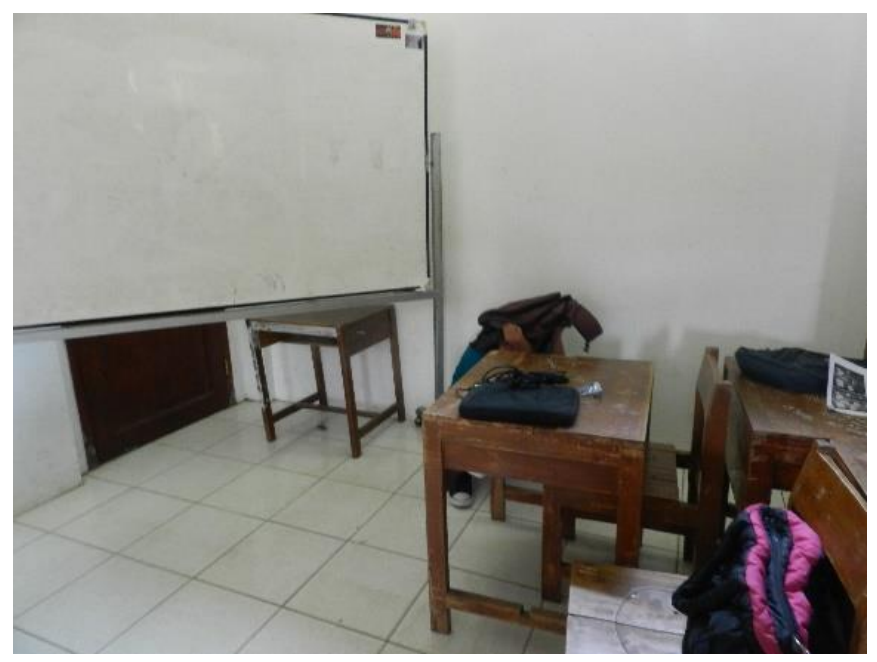

Gambar 5. Simulasi Terjadi Gempa

Setelah dilakukan kegiatan edukasi, siwa dan siwi SMK AD-Da'wah mulai memiliki pengetahuan bagaimana langkah-langkah yang harus dilakukan apabila terjadi gempa bumi. Hal ini terlihat dari hasil pre test dan post tes menunjukkan adanya perubahan pengetahuan siwa terhadap gempa bumi. Siswa sebelum diberikan edukasi memiliki nilai rata-rata 6 dan setelah diberikan edukasi nilai mahasiswa tersebut meningkat menjadi 8. Hasil pretest dan post test tentang pengetahuan gempa bumi yang dilakukan oleh siswa dan siwi SMK ADDA'wah dapat dlihat pada Gambar 6 dan Table 1. 


\section{Nilai Pre Test dan Post Test}

15

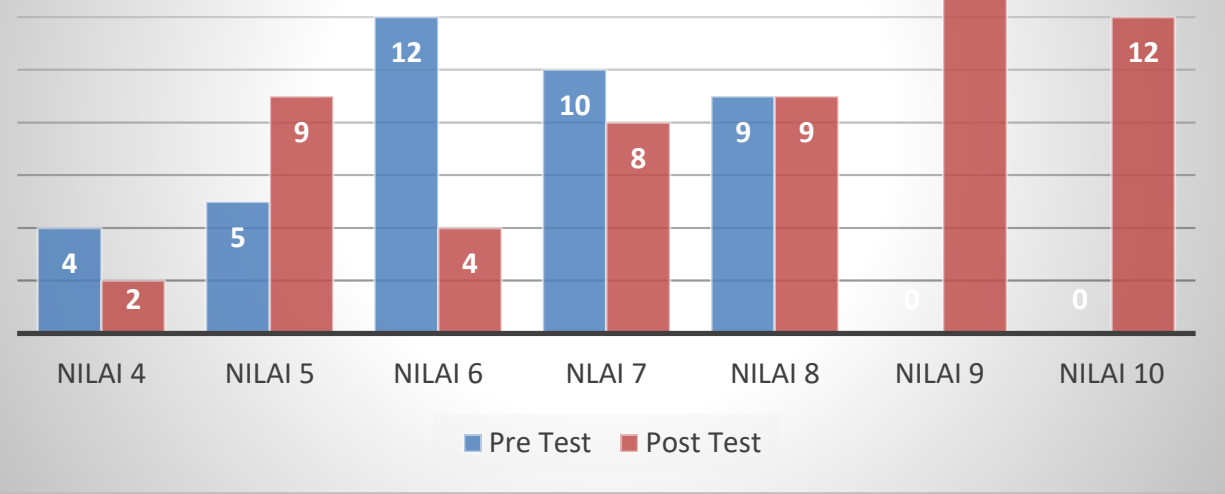

Gambar 6. Perbandingan nilai Pre Test dan Post Test

Tabel 1 Hasil Nilai Pre Test dan Post Test

\begin{tabular}{|c|c|c|c|}
\hline \multicolumn{2}{|c|}{ Hasil Nilai Pre Test } & \multicolumn{2}{c|}{ Hasil Nilai Post Test } \\
\hline NILAI & $\begin{array}{c}\text { JUMLAH } \\
\text { PESERTA }\end{array}$ & NILAI & $\begin{array}{c}\text { JUMLAH } \\
\text { PESERTA }\end{array}$ \\
\hline 4 & 4 Orang & 4 & 2 Orang \\
\hline 5 & 5 Orang & 5 & 9 Orang \\
\hline 6 & 12 Orang & 6 & 4 Orang \\
\hline 7 & 10 Orang & 7 & 8 Orang \\
\hline 8 & 9 Orang & 8 & 9 Orang \\
\hline 9 & 0 Orang & 9 & 15 Orang \\
\hline 10 & 0 Orang & 10 & 12 Orang \\
\hline Rata-Rata Nilai Pre Test $=\mathbf{6}$ & Rata-Rata Nilai Pre Test = 8 \\
\hline
\end{tabular}

Sumber : Hasil Analisis

Melalui kegiatan edukasi ini dihasilkan SMK AD-Da'wah sudah memahami pentingnya kesiapsiagaan terhadap bencana gempa bumi sehingga dapat mengurangi kepanikan warga, korban gempa dan kerusakan yang ditimbulkan akibat bencana gempa bumi.

Selama kegiatan berlangsung, terlihat antusias peserta yang cukup besar. Hal ini tampak dari semangat para peserta selama sesi paparan dan demonstrasi saat terjadi gempa serta adanya timbal balik dari peserta pada sesi tanya jawab. 


\section{KESIMPULAN}

Setelah kegiatan edukasi terlaksana, beberapa hal yang dapat dicapai adalah peserta memahami akan pentingnya kesiapsiagaan terhadap gempa bumi, peserta memahami akan langkah-langkah yang harus dilakukan saat sebelum terjadi gempa bumi, peserta memahami akan langkah-langkah yang harus dilakukan saat terjadi gempa bumi, peserta memahami akan langkah-langkah yang harus dilakukan saat setelah terjadi gempa bumi.

\section{SARAN}

Saran dalam kegiatan PKM ini adalah diharapkan kegiatan serupa dapat diadakan tidak hanya di lingkungan sekitar kampus STT-PLN, mengingat pentingnya kesiapsiagaan terhadap terjadinya gempa bumi. Selanjutnya adanya kelanjutan kegiatan, dengan fokus tidak hanya pada edukasi gempa bumi saja namun juga demonstrasi saat terjadi gempa. Selanjutnya diharapkan adanya kegiatan mengenai perencanaan jalur evakuasi bencana, mengingat pentingnya informasi tersebut untuk menghubungkan semua area ke area yang aman sebagai titik kumpul.

\section{UCAPAN TERIMA KASIH}

Penulis mengucapkan terima kasih kepada STT-PLN, SMK Ad-Da'wah, Seluruh dosen Teknik Sipil yang terlibat yang telah memberi dukungan yang membantu pelaksanaan kegiatan pengabdian pada masyarakat. Apabila terdapat banyak kekurangan dalam Artikel ini penyusun mohon maaf yang sebanyak-banyaknya. Semoga Artikel ini dapat bermanfaat untuk para pembacanya.

\section{DAFTAR PUSTAKA}

[1] Cahyadi, 1976. Lempeng Indonesia. Pustaka Jaya : Jakarta

[2] Direktorat BNPB. 2017. Buku Pedoman Kesiapsiagaan Bencana. "Membangun Kesadaran, Kewaspadaan, dan Kesiapsiagaan dalam Menghadapi Bencana".

[3] Kementerian Pendidikan Nasional-Badan Perencanaan Pembangunan Nasional. 2010. "Strategi Pengarusutamaan Pengurangan Risiko Bencana Di Sekolah, Gugus Tugas Pengarusutamaan Pengurangan RisikoBencana Dalam Sistem Pendidikan Nasional"

[4] Nungrat W. 2001. Kondisi Geologi Indonesia, Ganesha Press, Bandung.

[5] Pribadi, Khrisna S, dkk. 2008. Buku Pegangan Guru Pendidikan Siaga Bencana. Bandung : Pusat Mitigasi Bencana ITB 
[6] Reza,Muhammad. 2008. “Studi Mekanisme Sumber Gempa Bumi Nias 2005”, Program Pendidikan Diploma III, Jurusan Geofisika, Akademi Meteorologi dan Geofisika, Jakarta

[7] Robert W, 2017, Cara Evakuasi di Gedung Bertingkat Dengan Keadaan Darurat Seperti Gempa, http://www.earth-cycles.com/cara-evakuasi-di-gedung-bertingkat-dengankeadaan-darurat-seperti-gempa/, diakses pada Februari 2018

[8] Tri Wardana,Rahmadi.2008. "Analisa Statistik Tingkat Keaktifan Gempa Bumi di Daerah Jawa Timur dan Sekitarnya”, Program Pendidikan Diploma III, Jurusan Geofisika

[9] Wardhana Y. 1998. Geologi Indonesia. Makara Sains 23:1-5. 